Е.В. Комлева, Е.Н. Туманик ${ }^{*}$

Обзор научно-практической конференции «Декабристы в Забайкалье: вклад в изучение и развитие края»

doi:10.31518/2618-9100-2020-6-18

УДК 069.1, 908, 930.85

Выходные данные для цитирования:

Комлева Е.В., Туманик Е.Н. Обзор научнопрактической конференции «Декабристы в Забайкалье: вклад в изучение и развитие края» // Исторический курьер. 2020. № 6 (14). С. 220-223. URL: http://istkurier.ru/data/2020/ISTKURIER-20206-18.pdf
E.V. Komleva, E.N. Tumanik ${ }^{*}$

\section{Summary Report of the Scientific and Practical Conference "Decembrists in Transbaikalia: Contribution to the Study and Development of the Region”}

\author{
doi:10.31518/2618-9100-2020-6-18
}

How to cite:

Komleva E.V., Tumanik E.N. Summary Report of the Scientific and Practical Conference "Decembrists in Transbaikalia: Contribution to the Study and Development of the Region" // Historical Courier, 2020, No. 6 (14), pp. 220-223. [Available online:] http://istkurier.ru/data/2020/ISTKURIER-2020-618.pdf

Abstract. A brief summary report of the scientific and practical conference "Decembrists in Transbaikalia: contribution to the study and development of the region", organized by the Decembrist Museum in Chita and held on December 22-23, 2020 in online mode, is presented. The event brought together researchers from different cities of Russia who made reports on the Siberian exile of the participants of the December uprising, their memoir-epistolary heritage. Special attention was paid to the problems of preserving the memory of the Decembrists, popularizing the cultural and historical heritage left by them.

Keywords: Decembrists; exile; Siberia; Transbaikalia; cultural and historical heritage; preservation of memory.

The article has been received by the editor on 24.12.2020.

Full text of the article in Russian and references in English are available below.

Аннотация. Представлен краткий обзор научно-практической конференции «Декабристы в Забайкалье: вклад в изучение и развитие края», организованной Музеем декабристов в Чите и прошедшей 22-23 декабря 2020 г. в онлайн-режиме. Мероприятие объединило исследователей из разных городов России, выступивших с докладами о сибирской ссылке участников декабрьского восстания, их мемуарно-эпистолярном наследии. Особое внимание в рамках работы конференции было уделено проблемам сохранения памяти о декабристах, популяризации оставленного ими культурно-исторического наследия.

Ключевые слова: декабристы; ссылка; Сибирь; Забайкалье; культурно-историческое наследие; сохранение памяти.

В 2020 г. мы отмечаем 195-летие со дня событий на Сенатской площади. На этот же год приходится 35-летие основания Музея декабристов в Чите, сотрудники которого решили в честь юбилеев провести научно-практическую конференцию «Декабристы в Забайкалье:

\footnotetext{
* Комлева Евгения Владиславовна, кандидат исторических наук, Институт истории Сибирского отделения Российской академии наук, Новосибирск, Россия, e-mail: feodal@history.nsc.ru

Komleva Evgeniya V., Candidate of Historical Sciences, Institute of History of the Siberian Branch on the Russian Academy of Sciences, Novosibirsk, Russia, e-mail: feodal@history.nsc.ru

Туманик Екатерина Николаевна, кандидат исторических наук, Институт истории Сибирского отделения Российской академии наук, Новосибирск, Россия, e-mail: kattum@mail.ru

Tumanik Ekaterina N., Candidate of Historical Sciences, Institute of History of the Siberian Branch on the Russian Academy of Sciences, Novosibirsk, Russia, e-mail: kattum@mail.ru
} 
вклад в изучение и развитие края». Мероприятие прошло 22-23 декабря в онлайн-режиме, объединив исследователей из Москвы, Екатеринбурга, Ялуторовска, Туринска, Новосибирска, Новокузнецка, Минусинска, Иркутска, Читы. Предлагаем вниманию читателей краткий обзор конференции.

Конференцию открыла заведующая отделом «Музей декабристов» Забайкальского краевого краеведческого музея им. А.К. Кузнецова Любовь Ивановна Потехина, обратившись к собравшимся с краткими словами о памятных датах, которые пришлись на текущий год, о важности сохранения памяти об участниках восстания 14 декабря и о том вкладе, который они внесли в развитие Сибири. С приветствиями выступили директор Забайкальского краевого краеведческого музея Виктор Кириллович Колосов, представитель московского общества «Наследие декабристов» Наталья Игнатьевна Тюшкова, читинский краевед, журналист Людмила Ивановна Арзамасцева. Все они отметили выдающуюся роль декабристов в истории России, а также огромное значение их деятельности для культурного развития Сибири. В.К. Колосов обратил внимание на отмечающийся в последнее время рост негативного отношения к декабристам и их наследию в общественном сознании, что видно, в частности, при анализе информации, размещаемой в социальных сетях, и призвал всех заинтересованных лиц - сотрудников музеев, научное сообщество, краеведов - объединить усилия в борьбе с подобными тенденциями.

В первый день работы конференции было заслушано семь докладов. Кандидат исторических наук научный сотрудник Забайкальского краевого краеведческого музея им. А.К. Кузнецова Н.Н. Константинова осветила работу музея по изучению и популяризации наследия декабристов, затронув такие вопросы, как история создания музея, комплектование фондов, культурно-просветительные мероприятия. Доклад кандидата исторических наук старшего научного сотрудника Института истории Сибирского отделения Российской академии наук Е.Н. Туманик был посвящен пребыванию декабриста А.Н. Муравьева в забайкальской ссылке в г. Верхнеудинске, в частности, был рассмотрен эпистолярный корпус декабриста периода 1827-1828 гг., выделены как основные адресаты, так и темы переписки, дана оценка репрезентативности писем, показано отражение в них гражданскополитических взглядов А.Н. Муравьева накануне вступления в гражданскую службу в Сибири. Выступление автора научных работ по декабристской тематике Э.Б. Штеца было основано на анализе неопубликованной записки декабриста Дмитрия Иринарховича Заваилишина (1804-1892), повествующей о его жизни в г. Чите. Кандидат исторических наук старший научный сотрудник Института истории Сибирского отделения Российской академии наук Е.В. Комлева рассказала о взаимоотношениях сибирских купцов с декабристами и представила участникам конференции некоторые издания Института истории СО РАН. В видеосюжете, поступившем из Иркутского музея декабристов, директор музея Е.А. Добрынина познакомила присутствовавших с историей и работой этого просветительного учреждения. Большой интерес вызвало сообщение молодого экскурсовода из Екатеринбурга П.А. Ананьина о реализуемом в городе музейно-туристическом проекте «Декабристский лабиринт», главная цель которого - популяризация декабристского наследия. В свою очередь, заведующая отделом «Музей декабристов» Забайкальского краевого краеведческого музея им. А.К. Кузнецова Л.И. Потехина познакомила участников конференции с высоко оцененным читинской администрацией проектом туристического маршрута.

Во второй день работы конференции было представлено десять докладов и сообщений. Краевед из Новокузнецка В.С. Пилипенко посвятил свое выступление декабристам-участникам Отечественной войны 1812 г. Член Союза журналистов России и Российского общества историков-архивистов М.В. Забровская рассказала о научных занятиях декабристов на примере практического изучения ими популярного в XIX в. явления магнетизма. В ряде докладов были освещены разносторонние сферы деятельности декабристов в Сибири, способствовавшие освоению и культурно-экономическому развитию зауральских территорий. Библиотекарь отдела краеведения Музея истории здравоохранения Забайкальского края, преподаватель Читинского медицинского колледжа Е.Н. Виткаускас на базе матери- 
алов Музея истории здравоохранения Забайкальского края проанализировала вклад декабристов в развитие медицины, их подвижническую деятельность на благо населения региона. Научный сотрудник отдела «Музей декабристов» Минусинского регионального краеведческого музея им. Н.М. Мартьянова В.В. Ермилова рассказала о деятельности декабристов в области агрономии и сельскохозяйственного развития юга Сибири, подчеркнув ее решающее значение для качественных изменений в агросфере Минусинского округа. Научный сотрудник Туринского филиала Свердловского областного краеведческого музея им. О.Е. Клера О.А. Головизнина представила творческое и художественное наследие декабриста Василия Петровича Ивашева (1797-1840) и его супруги, доклад сопровождался презентацией, продемонстрировавшей опору на изобразительные источники - рисунки супругов, а также произведения декоративно-прикладного искусства (шитье, вышивки), созданные К.П. Ивашевой. Широкая историческая панорама города Минусинска, реконструированная на базе мемуаров декабриста Александра Петровича Беляева (1802-1887), была представлена в выступлении заведующей отделом «Музей декабристов» Минусинского регионального краеведческого музея им. Н.М. Мартьянова И.И. Негодиной. Заведующая Ялуторовским музейным комплексом Тюменского музейно-просветительского объединения И.В. Петелина рассказала об истории дома в Ялуторовске, который известен как дом Матвея Ивановича Муравьева-Апостола (1793-1886): была воссоздана история приобретения и перестройки дома декабристом, последующая судьба усадьбы вплоть до превращения ее в музей. В преддверии приближающегося в 2021 г. юбилея отмены крепостного права старший научный сотрудник отдела «Музей декабристов» Забайкальского краевого краеведческого музея им. А.К. Кузнецова А.И. Перфильева подготовила обзор деятельности декабристов по подготовке и проведению крестьянской реформы. Младший научный сотрудник Музея истории Забайкальской железной дороги О.С. Мурлина представила стендовый доклад «Опыт краеведческой работы на примере обращения к теме декабристов».

Отдельно следует отметить сообщение представлявшей московское общество «Наследие декабристов» Н.И. Тюшковой о Международном конкурсе «Товарищ, верь!..», направленном на приобщение молодежи к идейному, культурному и творческому наследию декабристов. Организаторы конкурса - Союз писателей России, Международный союз «Мужество и гуманизм», Международный Шуховский фонд и московское общество «Наследие декабристов». Конкурс опирается на методику патриотического воспитания молодежи через приобщение к наследию декабристов. В этом году на конкурс поступило более 200 работ. Особенно важным и приятным для организаторов конференции из Читинского музея декабристов можно считать то, что одним из дипломантов конкурса «Товарищ, верь!..» стала читинская школьница А. Городова, представившая историко-творческую работу о художнике Н.М. Полянском, посвятившем свое творчество декабристам.

По итогам работы конференции принята резолюция о важности сохранения декабристского наследия, о его глубокой воспитательной роли для подрастающего поколения, патриотическом значении дела декабристов, сохраняющего и сегодня свой просветительский потенциал, что ярко видно на примере деятельности сибирских музеев декабристов. В частности, в резолюции отмечены следующие решения:

«Обратиться к администрации г. Читы и Правительству Забайкальского края с предложением провести в 2025 г. ряд мероприятий, посвященных 200-летию восстания декабристов, с привлечением историков, музейных сотрудников, работников культуры из других регионов. Ориентировать мероприятия на духовно-нравственные аспекты наследия декабристов в целях формирования идеалов подрастающего поколения на примерах соотечественников, оказавших всестороннее влияние на развитие Забайкалья.

Считать необходимым продолжать популяризировать декабристское наследие с целью предупреждения наметившихся тенденций к искажению и вольной трактовке исторических фактов 1825 г.

В целях развития сотрудничества музеев и научной общественности провести в 2021 г. форум “По местам декабристов. Новые экскурсии и маршруты”. 
Опубликовать материалы I научно-практической онлайн-конференции “Декабристы в Забайкалье: вклад в изучение и развитие края”».

Статья поступила в редакцию 24.12.2020 г. 